\title{
Prevalence of Chlamydia trachomatis endocervical infection in systemic lupus erythematosus patients and evaluation of the risk for HPV-induced lesions
}

\author{
Licia CostaPinto - Viviana Gallazzi Olavarria - Maria Fernanda Rios Grassi • \\ Leomar D' Cirqueira Lyrio • Rone Peterson Cerqueira Oliveira • \\ Iuri Usêda Santana $\cdot$ Cristiane Bahiana Cruz $\cdot$ Mittermayer Barreto Santiago
}

Received: 8 December 2011/Accepted: 11 March 2012/Published online: 7 April 2012

(C) Springer-Verlag 2012

\begin{abstract}
Chlamydia trachomatis (CT) is the most common bacterial cause of sexually transmitted disease. It has been associated with arthritis and it is a risk factor for human papillomavirus (HPV)-induced lesions. There are few studies on the frequency of CT infection among systemic lupus erythematosus (SLE) patients. The aim of this study was to determine the prevalence of endocervical CT infection among SLE patients and evaluate whether or not $\mathrm{CT}$ infection is a risk factor for HPV-induced lesions. A cross-sectional study included a group of patients who fulfilled the American College Rheumatology criteria for a definite diagnosis of SLE and a control group of non-SLE female individuals from Bahia, Brazil. Polymerase chain reaction was used on endocervical swab specimens to test for CT; a gynecological examination including a cervical cytology and biopsy was done for the identification of HPV lesions. A total of 105 SLE patients were studied, and the control group was composed of 104 age-matched apparently normal women. The prevalence of CT endocervical
\end{abstract}

This article is part of Licia CostaPinto M.Sc Thesis of Bahiana School of Medicine and Public Health Post-Graduate Course.

L. CostaPinto · V. G. Olavarria · L. D. C. Lyrio ·

R. P. C. Oliveira - I. U. Santana - C. B. Cruz ·

M. B. Santiago $(\square)$

Escola Bahiana de Medicina e Saúde Pública, Av. D. João VI,

275, Brotas, Salvador, Bahia CEP: 40.290-000, Brazil

e-mail: mitter@svn.com.br

M. F. R. Grassi

Centro de Pesquisas Gonçalo Moniz/Fundação Oswaldo Cruz, Salvador, Bahia, Brazil

M. B. Santiago

SER (Serviços Especializados em Reumatologia) da Bahia,

Salvador, Brazil infection was $3.0 \%$ [confidence interval (CI) $95 \%=$ $0.6-8.0 \%]$ in the SLE group and $5.0 \% \quad(95 \%$ $\mathrm{CI}=2.0-11.0 \%)$ in the control group; the prevalence ratio was $0.60(95 \% \mathrm{CI}=0.1-2.5)$. The prevalence of vulvar condyloma was higher among SLE patients (11.0 vs. $1.0 \%, p<0.001)$, as were the prevalences of low-grade lesion (12.0 vs. $1.0 \%, p<0.001)$ and cervical intraepithelial neoplasia 1 ( 9.0 vs. $1.0 \%, p=0.02$ ). There was no association between the presence of HPV lesions and CT infections. However, the small number of patients with CT prevents a definite conclusion from being drawn. The prevalence of endocervical CT infection in women with SLE is low and similar to that of the normal population. This suggests that this infection has no role in the pathogenesis of SLE or the development of HPV-induced lesions.

Keywords Chlamydia trachomatis $\cdot$ Systemic lupus erythematosus · Human papillomavirus · Polymerase chain reaction

\section{Introduction}

The prevalence of Chlamydia trachomatis (CT) infection varies between 5.0 and $21.0 \%$ in the USA [1] and $3.0-10.0 \%$ in Europe [2-4]. In Brazil, it ranges between 3.0 and $21.0 \%$ [5-8]. These percentages vary based on the socioeconomic status and/or genetic background of the studied population, the age of the patients, from where the specimen was collected [urethra, vagina, cervix, urine, blood [9]] and the diagnostic method utilized. CT causes a variety of urogenital and extra-genital diseases such as pelvic inflammatory disease (PID) and blindness. It has also been associated with rheumatic disorders, particularly 
spondyloarthritis [10-15]. In addition, CT can facilitate the transmission of HIV (it increases the risk of HIV infection by 2-4 times) [14] and it is a possible cofactor for the progression of HPV-induced lesions and cervical cancer [16-18].

It is well known that patients with systemic lupus erythematosus (SLE) have a higher prevalence of certain infections [19-22] including HPV [23, 24], either by the disease itself or by the use of immunosuppressive drugs, but there has been no study on the prevalence of endocervical CT infection in relation to this condition.

The aim of this study was to investigate the prevalence of endocervical CT infection among SLE patients to and assess whether or not CT infection is a risk factor for HPVinduced lesions.

\section{Materials and methods}

This is a descriptive, cross-sectional study. A group of SLE female patients and an age-matched control group of healthy women followed at the outpatient clinics of the Escola Bahiana de Medicina e Saúde Pública in Salvador, Brazil, were included in this study. All SLE patients fulfilled the criteria for a definite diagnosis of SLE based on the guidelines from the American College of Rheumatology [25]. They were recruited between 2009 and 2010.

The age of the studied population ranged from 18 to 65 years; all patients had had sexual experience. Exclusion criteria were psychiatric disorders, pregnancy, early postpartum period, hysterectomy, or the use of any antibiotic in the 30 days prior to the examination. In the control group, individuals with any articular symptoms were excluded.

The study was approved by our institution's Ethics Committee. All patients signed an informed consent form prior to entry in the study. Each patient gave information about their medical history, household income and use of immunosuppressive drugs; each patient also underwent a physical examination and a gynecological evaluation which included colposcopic and cytology exams. A cervical biopsy was performed out in cases with an abnormal colposcopy. Colposcopic results were classified according to the International Federation for Cervical Pathology and Cytology [26]; for statistical analysis purpose, results were categorized into groups of inflammation, low-grade lesion [this group includes irregularities such as HPV and cervical intraepithelial neoplasia, (CIN) 1], high-grade lesion (CIN 2, CIN 3) and invasive cancer [27]. The biopsy results were analyzed in the following categories: cervical intraepithelial CIN 1, CIN 2 and CIN 3, cancer, invasive cervical cancer [28] and vulvar intraepithelial neoplasia (VIN 1, VIN 2 and VIN 3) [29].

Endocervical smears were collected using a sterile swab (J. Prolab ${ }^{\circledR}$ and $\mathrm{CRAL}^{\circledR}$ ). Polymerase chain reaction (PCR) testing was used to test for $\mathrm{CT}$ at the Advanced Laboratory of Public Health of the Oswald Cruz Foundation. The endocervical smears were collected in $400 \mu \mathrm{l}$ of TE [10 mM Tris- $\mathrm{HCl} \mathrm{pH} 8.0$ and $1 \mathrm{mM}$ ethylenediamine tetra-acetic acid (EDTA)] [30]. DNA extraction was made by Qiagen kit (Qiamp DNA Mini Kit ${ }^{\circledR}$ ). The samples were maintained at $-20{ }^{\circ} \mathrm{C}$ until used. The primers $\mathrm{KL} 1-5$ TCCGGAGCGAGTTACGAAGA $3^{\prime}$ and KL2-5'AAT CAATGCCCGGGATTGGT $3^{\prime}$ were used to amplify a 241 bp fragment of chlamydial plasmid (KL1 and KL2) [31]. Standard reaction conditions were used to amplify each reaction for a final volume of $25 \mu$ l. The reaction was composed of $13 \mu \mathrm{l}$ Top Taq Master Mix (Qiagen $\left.{ }^{\circledR}\right)(2 \times)$, $1 \mu \mathrm{l}$ of $\mathrm{KL} 1$ and KL2 primers $(10 \mathrm{pmol} / \mu \mathrm{l}), 2.5 \mu \mathrm{l}$ of CoralLoad Concentrate $(10 \times), 2.5 \mu \mathrm{l}$ of RNAase-free water and $5 \mu \mathrm{l}$ of DNA samples template (average $50 \mathrm{ng}$ / $\mu \mathrm{l})$. The amplification was done in an Applied Biosystems Veriti $^{\mathrm{TM}}$ Thermal Cycler with the following cycling temperatures: initial heating at $94{ }^{\circ} \mathrm{C}$ for $5 \mathrm{~min}, 35$ cycles of denaturation at $94{ }^{\circ} \mathrm{C}$ for $20 \mathrm{~s}$, annealing at $57{ }^{\circ} \mathrm{C}$ for $20 \mathrm{~s}$ and extension at $72{ }^{\circ} \mathrm{C}$ for $1 \mathrm{~min}$. In order to visualize the PCR product, a $2 \%$ agarose gel electrophoresis was applied and then stained with ethidium bromide.

The prevalence and prevalence ratios (Mantel-Haenszel) were presented in $95 \%$ confidence intervals (CI). Quantitative variables were presented as mean \pm SD or median and interquartile range, and qualitative variables were expressed as percentages. Statistical tests were chosen after normality tests. Means were compared with the Student's $t$-test or Mann-Whitney test, depending on the normality of the variable. Relationships between qualitative variables were studied using chi-square or Fisher's exact tests. Logistic regression was used to estimate the association between the $\mathrm{CT}$ test and each possible risk factor. It was estimated that 87 women with SLE were needed to calculate the prevalence of CT endocervical infection with a $95 \%$ CI (alpha of 0.05), considering an estimated prevalence of $6.0 \%$. Statistical analysis was performed with SPSS for Windows, version 17.0 (SPSS, Chicago, IL).

\section{Results}

Socio demographic and behavioral characteristics of the studied population

There were 105 women in the SLE group and 104 in the control group. The mean age was $38 \pm 11$ in SLE group and $36 \pm 11$ in the control group, $p=0.08$. There was a statistically significant difference between the household income of the two groups (44.0 vs. $62.0 \%, p=0.01)$, number of current smokers (4.0 vs. $11.0 \%, p=0.04)$ (Table 1) and age at first sexual intercourse $(20 \pm 4$ vs. 
Table 1 Socio-demographic and behavioral characteristics of the patients in the two study groups: systemic lupus erythematosus (SLE) and control

$S D$ standard deviation, ${ }^{\dagger} t$-test; $*$ chi-square test; ${ }^{a}$ Brazilian minimum wage: US $\$ 285$ per month; ** Fisher's exact test; $p<0.05=$ statistically significant

$18 \pm 4, p=0.01$ ) (Table 2). The mean duration of SLE was $9 \pm 6$ years. The SLE patients were using the following drugs: $59 \%$ prednisone, $24 \%$ azathioprine, $9 \%$ mycophenolate mofetil, $2 \%$ tacrolimus, $2 \%$ leflunomide and $1 \%$ cyclosporine.

Prevalence of Chlamydia trachomatis infection (PCR)

The prevalence of CT endocervical infection was $3.0 \%$ $(95 \% \mathrm{CI}=0.6-8.0 \%)$ in the SLE group and $5.0 \%(95 \%$ $\mathrm{CI}=2.0 \%-11.0 \%)$ in the control group, $p=0.49$ (Table 2); the prevalence ratio was $0.60 \quad(95 \%$ $\mathrm{CI}=0.1-2.5), p=0.47$.

In the control group, the following variables were analyzed using univariate analysis and found not to have statistical significance to CT infection: age at first sexual intercourse, number of partners, condom use and history of sexually transmitted diseases (STD) and cervical ectopy.

\section{Prevalence of HPV-induced lesions}

The prevalence of vulvar wart (condyloma) was higher among SLE patients than the control group (11.0 vs. $1.0 \%$, $p<0.001$ ), as was the prevalence of low-grade intraepithelial lesion (12.0 vs. $1.0 \%, p<0.001)$ and CIN $1(9.0$ vs. $1.0 \%, p=0.02$ ) (Table 3). Curiously, all SLE patients with HPV-induced lesions tested negative for CT infection.

\section{Discussion}

This study demonstrates for the first time the prevalence of endocervical CT infection among SLE patients. Based on the higher prevalence of infections observed in SLE patients secondary to the disease itself and/or the use of immunosuppressive drugs as well as on the described association of CT infection and the development of rheumatic diseases, a greater prevalence of uterine endocervical CT infection was expected in those patients. However, this study found the prevalence of CT endocervical infection to be similar in the SLE and control groups. Previous studies on women without SLE show similar findings [1, 2, 4, 6]. Aside from the age at first sexual activity (which was higher among SLE patients), other risk factors (current condom use, hormonal contraceptive use, number of partners and history of STD) for CT infection were similar between the two groups. Perhaps the higher concentrations of gamma interferon in frequently observed in SLE plasma $[32,33]$ are able to hold off the CT infection [34-37].

The hypothesis of molecular mimicry between microbial antigens and self-antigens has been described in several auto-immune conditions such as reactive arthritis, rheumatic fever and primary biliary cirrhosis (PBC). The present study, which finds the prevalence of CT infection to be similar between women with SLE and the normal population, suggests that this infectious agent has no role in
Table 2 Gynecological and obstetric features and prevalence of Chlamydia trachomatis $(\mathrm{CT})$ endocervical infection in the two study groups: systemic lupus erythematosus (SLE) and control

$S D$ standard deviation, $S T D$ sexually transmitted disease, $I Q$ interquartile range, ${ }^{\dagger} t$-test, ${ }^{\dagger}$ Mann-Whitney test, * chisquare test, $* *$ Fisher's exact test, $p<0.05=$ statistically significant

\begin{tabular}{|c|c|c|c|c|c|}
\hline \multirow[t]{2}{*}{ Variables } & \multicolumn{2}{|c|}{$\begin{array}{l}\text { SLE group } \\
(N=105)\end{array}$} & \multicolumn{2}{|c|}{$\begin{array}{l}\text { Control group } \\
(N=104)\end{array}$} & \multirow[t]{2}{*}{$p$ value } \\
\hline & $N$ & & $N$ & & \\
\hline Age at first sexual intercourse (mean \pm SD) & 105 & $20 \pm 4$ & 104 & $18 \pm 4$ & $0.01^{\dagger}$ \\
\hline $\begin{array}{l}\text { Number of sexual partners } \\
\text { (median, IQ) }\end{array}$ & 105 & $2(1-4)$ & 104 & $3(2-4)$ & $0.11^{\dagger \dagger}$ \\
\hline Current condom use $(\%)$ & 14 & 13 & 15 & 14 & $0.82 *$ \\
\hline Hormonal contraceptive $(\%)$ & 7 & 7 & 5 & 5 & $0.56^{*}$ \\
\hline Previous STD (\%) & 23 & 22 & 13 & 12 & $0.07 *$ \\
\hline Parity (median, IQ) & 104 & $1(0-2)$ & 104 & $2(1-2)$ & $0.25^{\dagger \dagger}$ \\
\hline Number of abortions (median, IQ) & 104 & $0(0-1)$ & 104 & $0(0-1)$ & $0.32^{\dagger \dagger}$ \\
\hline Genital CT infection (\%) & 105 & 3 & 104 & 5 & $0.49 * *$ \\
\hline
\end{tabular}


Table 3 Cytologic and histologic findings in the two study groups: systemic lupus erythematosus (SLE) and control
* Chi-square test, ** Fisher's exact test, ASCUS atypical squamous cells of undetermined significance, LGSIL low-grade intraepithelial squamous lesion, HGSIL high-grade

intraepithelial squamous lesion, $C I N$ cervical intraepithelial neoplasia, VIN vulvar intraepithelial neoplasia, $p<0.05=$ statistically significant

\begin{tabular}{|c|c|c|c|c|c|}
\hline \multirow[t]{2}{*}{ Variables } & \multicolumn{2}{|c|}{$\begin{array}{l}\text { SLE group } \\
(N=105)\end{array}$} & \multicolumn{2}{|c|}{$\begin{array}{l}\text { Control group } \\
(N=104)\end{array}$} & \multirow[t]{2}{*}{$p$ value } \\
\hline & $N$ & $\%$ & $N$ & $\%$ & \\
\hline \multicolumn{6}{|l|}{ Cytology (Pap smear) } \\
\hline Inflammation & 55 & 52 & 49 & 47 & $0.45^{*}$ \\
\hline ASCUS & 1 & 1 & 0 & 0 & $1.00 * *$ \\
\hline LGSIL & 13 & 12 & 1 & 1 & $<0.001 * *$ \\
\hline HGSIL & 4 & 4 & 0 & 0 & $0.12 * *$ \\
\hline \multicolumn{6}{|l|}{ Histology } \\
\hline Cervical wart & 3 & 3 & 0 & 0 & $0.25 * *$ \\
\hline Vaginal wart & 7 & 7 & 0 & 0 & $0.01 * *$ \\
\hline Vulvar wart & 12 & 11 & 1 & 1 & $<0.001 * *$ \\
\hline CIN 1 & 9 & 9 & 1 & 1 & $0.02 * *$ \\
\hline CIN 2 & 1 & 1 & 0 & 0 & $1.00 * *$ \\
\hline CIN 3 & 1 & 1 & 0 & 0 & $1.00 * *$ \\
\hline VIN 2 & 1 & 1 & 0 & 0 & $1.00 * *$ \\
\hline VIN 3 & 1 & 1 & 0 & 0 & $1.00 * *$ \\
\hline $\begin{array}{l}\text { Vulvar invasive } \\
\text { squamous carcinoma }\end{array}$ & 1 & 1 & 0 & 0 & $1.00 * *$ \\
\hline
\end{tabular}

the pathogenesis of SLE. Leung et al. [38] researched the relationship between Chlamydia infection and PBC through serological tests (immunoblotting) and failed to demonstrate any association. Moreover, 20 SLE serum samples were included in that study and none had reactivity to CT. Similarly, Keat et al. [12] while studying the evidence of CT infection in sexually acquired reactive arthritis (SARA) used SLE, rheumatoid arthritis, ankylosing spondylitis and healthy male sera as controls. The serologic IgG antibody titers to CT in these control groups were essentially similar but they differed markedly from that in the SARA group. In another study, Kitumnuaypong et al. [9] performed a PCR analysis for CT 16srRNA and major outer membrane protein (MOMP) on DNA extracted from peripheral blood mononuclear cells in 28 SLE patients. None were positive for CT.

The higher prevalence of HPV-induced lesions among the SLE group was in agreement with the findings of other studies [23, 24, 39, 40]. Although an association has been described between HPV-induced lesions and CT infection in patients without SLE, this study found no such association. It has been speculated that CT promotes HPV persistence, leading to the development of HPV-induced lesions and even cervical cancer [14, 17, 18, 41-43]. However, this subject is a matter of controversy in the literature [44-48].

An unexpected finding of this study was the absence of association between HPV lesions and CT infection. However, it should not be interpreted as if CT confers protection against HPV infection since in previous studies from our institution which included the same population of patients we demonstrated a prevalence of HPV infection by PCR of $80 \%$ and some of the patients infected by CT also had HPV in endocervical smear [49]. Moreover, evidence about the role of $\mathrm{CT}$ infection on the predisposition for HPV infection working as a cofactor is subject of criticism as the odds ratio for such association in several studies are around 2 with CI very close to 1 , not excluding the possibility that the association of endocervical CT and HPV infection is a simple coincidence in people sharing the same epidemiologic profile.

In conclusion, the rate of endocervical CT infection among patients with SLE is low and similar to that of nonSLE individuals, which suggests that this type of infection has no role in the pathogenesis of the SLE.

Acknowledgments We thank Dr. Martha Silveira and Adelvani Boa Morte, librarians at Centro de Pesquisas Gonçalo Moniz/Fundação Oswaldo Cruz, Salvador; Drs. Eliana de Paula Santos, Margarida Santos Matos, Ana Paula Monteiro, Mrs. Caroline Gaspar and all other staff of the Escola Bahiana de Medicina e Saúde Pública. MS receives a grant from the National Council for Scientific and Technological Development $(\mathrm{CNPq})$.

Conflict of interest The authors have no conflicts of interest that are directly relevant to the content of this manuscript.

\section{References}

1. CDC Grand Rounds (2011) Chlamydia prevention: challenges and strategies for reducing disease burden and sequelae. MMWR Morb Mortal Wkly Rep 60(12):370-373 
2. Oakeshott P, Kerry S, Aghaizu A, Atherton H, Hay S, TaylorRobinson D et al (2010) Randomised controlled trial of screening for Chlamydia trachomatis to prevent pelvic inflammatory disease: the POPI (prevention of pelvic infection) trial. BMJ 340:c1642. doi:10.1136/bmj.c1642

3. Unemo M, Rossouw A, James V, Jenkins C (2009) Can the Swedish new variant of Chlamydia trachomatis (nvCT) be detected by UK NEQAS participants from seventeen European countries and five additional countries/regions in 2009? Euro Surveill 14(19):pii=19206. http://www.eurosurveillance.org/ ViewArticle.aspx?ArticleId=19206

4. Wilson JS, Honey E, Templeton A, Paavonen J, Mardh PA, Stray-Pedersen B (2002) A systematic review of the prevalence of Chlamydia trachomatis among European women. Hum Reprod Update 8(4):385-394

5. de Codes JS, Cohen DA, de Melo NA, Teixeira GG, Leal AS, Silva TJ et al (2006) Screening of sexually transmitted diseases in clinical and non-clinical settings in Salvador, Bahia, Brazil. Cad Saude Publica 22(2):325-334

6. Eleuterio RMN, Eleuterio J Jr, Giraldo PC, Muniz AMV (2007) Cervicite por Chlamydia trachomatis em mulheres sexualmente ativas atendidas em um serviço privado de ginecologia na cidade de Fortaleza. Rev Bras Anal Clin (4):287-290

7. Fernandes AM, Daher G, Nuzzi RX, Petta CA (2009) Chlamydia trachomatis and Neisseria gonorrhoeae among women in a family planning clinic. Rev Bras Ginecol Obstet 31(5):235-240

8. Igansi C (2005) Prevalência de Papilomavírus Humano (HPV) e Chlamydia trachomatis e sua associação com lesões cervicais em uma amostra de mulheres assintomáticas de Porto Alegre. Universidade Federal do Rio Grande do Sul (Thesis)

9. Kitumnuaypong T, Scalzi LV, Nalbant S, Von Feldt JM, Schumacher HR Jr (2004) Is there a role for Chlamydia pneumoniae infection in systemic lupus erythematosus and in the associated atherosclerotic cardiovascular disease? Clin Exp Rheumatol 22(3):339-342

10. Dejmoková H, Drazdakowá M, Mares Z et al (2005) Chlamydia trachomatis and Chlamydophilla pneumoniae antibodies in a cohort of rheumatic patients. Ceska Revmatologie 13(1):3-7

11. Fernandez RN, Ximenes AC, Alves MF (2005) Detecção do DNA de Chlamydia trachomatis em espondiloartropatias e artrite reumatóide. Rev Bras Reumatol 45(5):1-12

12. Keat AC, Thomas BJ, Taylor-Robinson D, Pegrum GD, Maini RN, Scott JT (1980) Evidence of Chlamydia trachomatis infection in sexually acquired reactive arthritis. Ann Rheum Dis 39(5):431-437

13. Kuipers JG, Sibilia J, Bas S, Gaston H, Granfors K, Vischer TL et al (2009) Reactive and undifferentiated arthritis in North Africa: use of PCR for detection of Chlamydia trachomatis. Clin Rheumatol 28(1):11-16

14. Sweet RL, Gibbs RS (2009) Chlamydial infectious. In: Sweet RL, Gibbs RS (eds) Infectious disease of the female genital tract, 5th edn. Lippincott Williams and Wilkins, Philadelphia, pp 18-40

15. Zeidler H, Kuipers J, Kohler L (2004) Chlamydia-induced arthritis. Curr Opin Rheumatol 16(4):380-392

16. Giuliano AR, Denman C, de Guernsey ZJ, Navarro Henze JL, Ortega L, Djambazov B et al (2001) Design and results of the USA-Mexico border human papillomavirus (HPV), cervical dysplasia, and Chlamydia trachomatis study. Rev Panam Salud Publica 9(3):172-181

17. Lehtinen M, Ault KA, Lyytikainen E, Dillner J, Garland SM, Ferris DG et al (2011) Chlamydia trachomatis infection and risk of cervical intraepithelial neoplasia. Sex Transm Infect 87(5):372-376

18. Marcolino LD, Polettini J, Tristão AR, Marques MEA et al (2008) Coinfecção de Chlamydia trachomatis e HPV em mulheres com condiloma cuminado. DST J Bras Doenças Sex Transm 20(2):87-92

19. Doria A, Canova M, Tonon M, Zen M, Rampudda E, Bassi N et al (2008) Infections as triggers and complications of systemic lupus erythematosus. Autoimmun Rev 8(1):24-28

20. Navarra SV, Leynes MS (2010) Infections in systemic lupus erythematosus. Lupus 19(12):1419-1424

21. Zandman-Goddard G, Shoenfeld Y (2005) Infections and SLE. Autoimmunity 38(7):473-485

22. Zonana-Nacach A, Camargo-Coronel A, Yanez P, Sanchez L, Jimenez-Balderas FJ, Fraga A (2001) Infections in outpatients with systemic lupus erythematosus: a prospective study. Lupus 10(7):505-510

23. Klumb EM, Pinto A, Jesus G, Araujo JM, Jascone L, Gayer C et al (2010) Are women with lupus at higher risk of HPV infection? Lupus 19(13):1485-1491

24. Santana IU, Gomes AN, Lyrio LD, Rios Grassi MF, Santiago MB (2011) Systemic lupus erythematosus, human papillomavirus infection, cervical pre-malignant and malignant lesions: a systematic review. Clin Rheumatol 30(5):665-672

25. Hochberg MC (1997) Updating the American College of Rheumatology revised criteria for the classification of systemic lupus erythematosus. Arthritis Rheum 40(9): 1725

26. Hammes LS, Naud P, Passos EP, Matos J, Brouwers K, Rivoire $\mathrm{W}$ et al (2007) Value of the international federation for cervical pathology and colposcopy (IFCPC) terminology in predicting cervical disease. J Low Genit Tract Dis 11(3):158-165

27. Solomon D, Davey D, Kurman R, Moriarty A, O'Connor D, Prey M et al (2002) The 2001 Bethesda System: terminology for reporting results of cervical cytology. JAMA 287(16):2114-2119

28. Richart RM (1990) A modified terminology for cervical intraepithelial neoplasia. Obstet Gynecol 75(1):131-133

29. Gerber S, Tonna SD, Delaloye JF (2008) A new classification of vulvar intraepithelial neoplasia (VIN). Rev Med Suisse 4(176): 2281-2285

30. Santos C, Teixeira F, Vicente A, Astolfi-Filho S (2003) Detection of Chlamydia trachomatis in endocervical smears of sexually active women in Manaus-AM, Brazil, by PCR. Braz J Infect Dis 7(2):91-95

31. Mahony JB, Luinstra KE, Sellors JW, Chernesky MA (1993) Comparison of plasmid- and chromosome-based polymerase chain reaction assays for detecting Chlamydia trachomatis nucleic acids. J Clin Microbiol 31(7):1753-1758

32. al-Janadi M, al-Balla S, al-Dalaan A, Raziuddin S (1993) Cytokine profile in systemic lupus erythematosus, rheumatoid arthritis, and other rheumatic diseases. J Clin Immunol 13(1):58-67

33. Crow MK, Kirou KA (2007) Cytokines and interferons in lupus. In: Wallace DJ, Hahn BH (ed) Dubois'Lupus Erythematosus, 7th edn. Lippincott William and Wilkins, Philadelphia, pp 161-175

34. Cheng C, Cruz-Fisher MI, Tifrea D, Pal S, Wizel B, de la Maza LM (2011) Induction of protection in mice against a respiratory challenge by a vaccine formulated with the Chlamydia major outer membrane protein adjuvanted with IC31(R). Vaccine 29(13):2437-2443

35. Gondek DC, Roan NR, Starnbach MN (2009) T cell responses in the absence of IFN-gamma exacerbate uterine infection with Chlamydia trachomatis. J Immunol 183(2):1313-1319

36. Morrison RP (2003) New insights into a persistent problemchlamydial infections. J Clin Invest 111(11):1647-1649

37. Sun G, Pal S, Weiland J, Peterson EM, de la Maza LM (2009) Protection against an intranasal challenge by vaccines formulated with native and recombinant preparations of the Chlamydia trachomatis major outer membrane protein. Vaccine 27(36): 5020-5025

38. Leung PS, Park O, Matsumura S, Ansari AA, Coppel RL, Gershwin ME (2003) Is there a relation between Chlamydia 
infection and primary biliary cirrhosis? Clin Dev Immunol 10(2-4):227-233

39. Tam LS, Chan AY, Chan PK, Chang AR, Li EK (2004) Increased prevalence of squamous intraepithelial lesions in systemic lupus erythematosus: association with human papillomavirus infection. Arthritis Rheum 50(11):3619-3625

40. Tam LS, Chan PK, Ho SC, Yu MM, Yim SF, Cheung TH et al (2010) Natural history of cervical papilloma virus infection in systemic lupus erythematosus - a prospective cohort study. J Rheumatol 37(2):330-340

41. Madeleine MM, Anttila T, Schwartz SM, Saikku P, Leinonen M, Carter JJ et al (2007) Risk of cervical cancer associated with Chlamydia trachomatis antibodies by histology, HPV type and HPV cofactors. Int J Cancer 120(3):650-655

42. Simonetti AC, Melo JH, de Souza PR, Bruneska D, de Lima Filho JL (2009) Immunological's host profile for HPV and Chlamydia trachomatis, a cervical cancer cofactor. Microbes Infect 11(4):435-442

43. Tamim H, Finan RR, Sharida HE, Rashid M, Almawi WY (2002) Cervicovaginal coinfections with human papillomavirus and Chlamydia trachomatis. Diagn Microbiol Infect Dis 43(4):277-281

44. Calil LN, Igansi CN, Meurer L, Edelweiss MI, Bozzetti MC (2011) Chlamydia trachomatis and human papillomavirus coinfection: association with p16INK4a and Ki67 expression in biopsies of patients with pre-neoplastic and neoplastic lesions. Braz J Infect Dis 15(2):126-131

45. Claas EC, Melchers WJ, Niesters HG, van MR, Stolz E, Quint WG (1992) Infections of the cervix uteri with human papillomavirus and Chlamydia trachomatis. J Med Virol 37(1):54-57

46. Edelman M, Fox A, Alderman E, Neal W, Shapiro A, Silver EJ et al (2000) Cervical papanicolaou smear abnormalities and Chlamydia trachomatis in sexually active adolescent females. J Pediatr Adolesc Gynecol 13(2):65-69

47. Mitrani-Rosenbaum S, Tsvieli R, Lavie O, Boldes R, Anteby E, Shimonovitch S et al (1994) Simultaneous detection of three common sexually transmitted agents by polymerase chain reaction. Am J Obstet Gynecol 171(3):784-790

48. Reesink-Peters N, Ossewaarde JM, Van Der Zee AG, Quint WG, Burger MP, Adriaanse AH (2001) No association of anti-Chlamydia trachomatis antibodies and severity of cervical neoplasia. Sex Transm Infect 77(2):101-102

49. Lyrio LD. Prevalence oF endocervical HPV in systemic lupus erythematosus Thesis presented at Escola Bahiana de Medicina e Saúde Pública, Bahia, Brazil; 2011 